\title{
Seleksi Calon Karyawan Pada Perusahaan Menggunakan Metode AHP Di STMIK Atma Luhur Pangkalpinang
}

\author{
Fitriyani ${ }^{[1]}$, Elly Yanuarti ${ }^{[2]}$ \\ Program Studi Sistem Informasi ${ }^{[1][2]}$ \\ STMIK Atma Luhur, Indonesia \\ email: fitriyani@atmaluhur.ac.id ${ }^{[1]}$, elly@atmaluhur.ac.id ${ }^{[2]}$
}

\begin{abstract}
Abstrak - Proses seleksi merupakan proses pencarian dan penarikan tenaga kerja yang memiliki potensi untuk mengisi lowongan pekerjaan, tenaga kerja yang berkualitas sangat berpengaruh pada kemajuan perusahaan. Kesalahan dalam memilih seorang karyawan tentunya akan membawa pengaruh negatif bagi kinerja perusahaan. Latar belakang masalah yang terjadi saat ini adalah dalam proses rekrutmen karyawan hanya mengandalkan seleksi berkas dan proses wawancara tanpa melihat kemampuan calon karyawan. Metode analisis data yang digunakan adalah AHP (Analytical Hierarki Process) yaitu pendekatan yang digunakan berdasarkan analisis kebijakan yang bertujuan untuk mendapatkan keputusan yang tepat dan optimal bagi perusahaan. Sistem pendukung keputusan dirancang untuk mendukung seluruh tahap pengambilan keputusan mulai dari mengidentifikasikan masalah, memilih data yang relevan, dan menentukan pendekatan yang digunakan dalam proses pengambilan keputusan, sampai mengevaluasi pemilihan alternative-alternatif yang ada didukung oleh software Expert Choice 2000.
\end{abstract}

Kata Kunci - Seleksi Karyawan, AHP (Analytical Hierarchy Process), Expert Choice 2000.

\section{PENDAHULUAN}

Keberhasilan perusahaan dalam menjalankan usahanya sangat ditentukan oleh kualitas karyawan yang ada didalamnya. Untuk memperoleh karyawan-karyawan yang berkualitas yang dibutuhkan, perusahaan mengadakan proses seleksi dalam perekrutan karyawan baru. Namun, tidak jarang proses seleksi ini tidak terlalu memberikan pengaruh karena masih berlakunya sistem nepotisme dalam proses perekrutan karyawan baru, sehingga tidak jarang karyawan yang direkrut tidak memenuhi standard kualitas dan kualifikasi kebutuhan perusahaan.

Proses seleksi bukanlah kegiatan yang berdiri sendiri. Artinya dalam melakukan kegiatan seleksi berbagai masukan perlu pula diperhitungkan dan dipertimbangkan. Seleksi merupakan proses untuk memutuskan karyawan yang tepat dari sekumpulan calon karyawan yang dapat melalui proses perekrutan, baik perekrutan internal maupun eksternal. Proses ini seperti halnya rekrutmen, merupakan kegiatan yang sangat penting sebab hasil yang didapat dari perekrutan tidak menjamin bahwa seluruh calon yang direkrut sesuai dengan perusahaan.

Permasalahan yang terjadi pada sistem manual adalah setiap berkas yang masuk, tidak langsung diproses, sehingga calon karyawan harus menunggu lama untuk mendapatkan informasi apakah berkas tersebut sudah diproses atau belum dan kadang-kadang berkas yang masuk tanpa ada kabar berita apakah calon karyawan bisa lolos ke tahap selanjutnya ataukah tidak. Dalam mengambil keputusan, tidak jelas kriteria yang dipakai oleh manajemen untuk menentukan calon pelamar tersebut diterima atau tidak.

Tujuan utama dari proses seleksi karyawan adalah untuk mendapatkan orang yang tepat bagi suatu jabatan atau tempat tertentu, sehingga orang tersebut mampu bekerja secara optimal dan dapat bertahan di perusahaan dalam jangka waktu yang lama. Proses seleksi karyawan ini membutuhkan waktu yang lama dan sangat terbuka peluang untuk melakukan kesalahan dalam menentukan orang yang tepat. Mengingat sangat pentingnya proses seleksi karyawan bagi perusahaan, diharapkan dengan adanya proses seleksi yang baik dan efektif serta selektif yang sangat berdampak bagi perkembangan perusahaan kedepannya untuk memperoleh sumber daya yang berkualitas.

Pada penelitian sebelumnya oleh Arif Harjanto, peneliti hanya membuat sistem seleksi karyawan berdasarkan hasil tes psikologi kepribadian saja. ${ }^{[10]}$ Untuk itulah, peneliti merasa perlu untuk membuat penelitian dengan menampilkan kriteria yang lebih lengkap agar hasilnya dapat diandalkan.

\section{LANDASAN TEORI}

\section{A. Pengertian Sistem}

Pengertian Sistem adalah suatu kesatuan prosedur atau komponen yang saling berkaitan satu dengan yang lainnya bekerja bersama sama sesuai dengan aturan yang diterapkan 
sehingga membentuk suatu tujuan yang sama. dimana dalam sebuah sistem bila terjadi satu bagian saja yang tidak bekerja atau rusak maka suatu tujuan bisa terjadi kesalahan hasilnya atau outputnya.

\section{B. Pengertian Keputusan}

Keputusan adalah suatu reaksi terhadap beberapa solusi alternatif yang dilakukan secara sadar dengan cara menganalisa kemungkinan-kemungkinan dari alternatif tersebut bersama konsekuensinya. Setiap keputusan akan membuat pilihan terakhir, dapat berupa tindakan atau opini. Itu semua bermula ketika kita perlu untuk melakukan sesuatu tetapi tidak tahu apa yang harus dilakukan. Untuk itu keputusan dapat dirasakan rasional atau irrasional dan dapat berdasarkan asumsi kuat atau asumsi lemah.

\section{Pengertian Pengambilan Keputusan}

Pengambilan keputusan merupakan proses pemilihan alternatif tindakan untuk mencapai tujuan atau sasaran tertentu. Pengambilan keputusan dilakukan dengan pendekatan sistematis terhadap permasalahan melalui proses pengumpulan data menjadi informasi serta ditambah dengan faktor - faktor yang perlu dipertimbangkan dalam pengambilan keputusan.

\section{Sistem Pendukung Keputusan}

Sistem pendukung keputusan (decision support system atau DSS) adalah sistem informasi berbasis komputer yang menyediakan dukungan informasi interaktif bagi manajer dan praktisi bisnis selamam proses pengambilan keputusan. Sistem pendukung keputusan menggunakan (1)model analitis, (2) database khusus, (3) penilaian dan pandangan pembuat keputusan, dan (4) proses permodelan berbasis computer yang interaktif untuk mendukung pembuatan keputusan bisnis yang semi terstruktur dan tak terstruktur.

1) Karakteristik SPK

a. Sistem Pendukung Keputusan dirancang untuk membantu pengambil keputusan dalam memecahkan masalah yang sifatnya semi terstruktur ataupun tidak terstruktur dengan menambahkan kebijaksanaan manusia dan informasi komputerisasi.

b. Dalam proses pengolahannya, sistem pendukung keputusan mengkombinasikan penggunaan modelmodel analisis dengan teknik pemasukan data konvensional serta fungsi-fungsi pencari / interogasi informasi.

c. Sistem Pendukung Keputusan, dirancang sedemikian rupa sehingga dapat digunakan/dioperasikan dengan mudah.

d. Sistem Pendukung Keputusan dirancang dengan menekankan pada aspek fleksibilitas serta kemampuan adaptasi yang tinggi.

2) Komponen SPK a. Data Management. Termasuk database, yang mengandung data yang relevan untuk berbagai situasi dan diatur oleh software yang disebut Database Management Systems (DBMS)

b. Model Management. Melibatkan model finansial, statistikal, management science, atau berbagai model kuantitatif lainnya, sehingga dapat memberikan ke sistem suatu kemampuan analitis, dan manajemen software yang diperlukan.

c. Commication (dialog subsystem). User dapat berkomunikasi dan memberikan perintah pada DSS melalui subsistem ini. Ini berarti menyediakan antarmuka.

d. Knowledge Management. Subsistem optional ini dapat mendukung subsistem lain atau bertindak sebagai komponen yang berdiri sendiri.

\section{E. Analytical Hierarchy Process $(A H P)$}

AHP merupakan suatu model pendukung keputusan yang dikembangkan oleh Thomas L. Saaty. Model pendukung keputusan ini akan menguraikan masalah multi faktor atau multi kriteria yang kompleks menjadi suatu hirarki. Hirarki didefinisikan sebagai suatu representasi dari sebuah permasalahan yang kompleks dalam suatu struktur multi level dimana level pertama adalah tujuan, yang diikuti level faktor, kriteria, sub kriteria, dan seterusnya ke bawah hingga level terakhir dari alternatif. Dengan hirarki, suatu masalah yang kompleks dapat diuraikan ke dalam kelompok-kelompoknya yang kemudian diatur menjadi suatu bentuk hirarki sehingga permasalahan akan tampak lebih terstruktur dan sistematis. AHP sering digunakan sebagai metode pemecahan masalah dibanding dengan metode yang lain karena alasan-alasan sebagai berikut :

1) Struktur yang berhirarki, sebagai konsekuesi dari kriteria yang dipilih, sampai pada subkriteria yang paling dalam.

2) Memperhitungkan validitas sampai dengan batas toleransi inkonsistensi berbagai kriteria dan alternatif yang dipilih oleh pengambil keputusan.

3) Memperhitungkan daya tahan output analisis sensitivitas pengambilan keputusan.

\section{F. Tahapan AHP}

Dalam metode AHP dilakukan langkah-langkah sebagai berikut :

1) Mendefinisikan masalah dan menentukan solusi yang diinginkan.

Dalam tahap ini kita berusaha menentukan masalah yang akan kita pecahkan secara jelas, detail dan mudah dipahami. Dari masalah yang ada kita coba tentukan solusi yang mungkin cocok bagi masalah tersebut. Solusi dari masalah mungkin berjumlah 
lebih dari satu. Solusi tersebut nantinya kita kembangkan lebih lanjut dalam tahap berikutnya.

2) Membuat struktur hierarki yang diawali dengan tujuan utama.

Setelah menyusun tujuan utama sebagai level teratas akan disusun level hirarki yang berada di bawahnya yaitu kriteria-kriteria yang cocok untuk mempertimbangkan atau menilai alternatif yang kita berikan dan menentukan alternatif tersebut. Tiap kriteria mempunyai intensitas yang berbeda-beda. Hirarki dilanjutkan dengan subkriteria (jika mungkin diperlukan).

3) Membuat matrik perbandingan berpasangan yang menggambarkan kontribusi relatif atau pengaruh setiap elemen terhadap tujuan atau kriteria yang setingkat di atasnya.

Matriks yang digunakan bersifat sederhana, memiliki kedudukan kuat untuk kerangka konsistensi, mendapatkan informasi lain yang mungkin dibutuhkan dengan semua perbandingan yang mungkin dan mampu menganalisis kepekaan prioritas secara keseluruhan untuk perubahan pertimbangan. Pendekatan dengan matriks mencerminkan aspek ganda dalam prioritas yaitu mendominasi dan didominasi. Perbandingan dilakukan berdasarkan judgment dari pengambil keputusan dengan menilai tingkat kepentingan suatu elemen dibandingkan elemen lainnya. Untuk memulai proses perbandingan berpasangan dipilih sebuah kriteria dari level paling atas hirarki misalnya $\mathrm{K}$ dan kemudian dari level di bawahnya diambil elemen yang akan dibandingkan misalnya E1,E2,E3,E4,E5.

4) Melakukan Mendefinisikan perbandingan berpasangan sehingga diperoleh jumlah penilaian seluruhnya sebanyak $n \times[(n-1) / 2]$ buah, dengan $n$ adalah banyaknya elemen yang dibandingkan.

Hasil perbandingan dari masing-masing elemen akan berupa angka dari 1 sampai 9 yang menunjukkan perbandingan tingkat kepentingan suatu elemen. Apabila suatu elemen dalam matriks dibandingkan dengan dirinya sendiri maka hasil perbandingan diberi nilai 1 . Skala 9 telah terbukti dapat diterima dan bisa membedakan intensitas antar elemen. Hasil perbandingan tersebut diisikan pada sel yang bersesuaian dengan elemen yang dibandingkan. Skala perbandingan perbandingan berpasangan dan maknanya yang diperkenalkan oleh Saaty bisa dilihat di bawah.

Intensitas Kepentingan

1 = Kedua elemen sama pentingnya, Dua elemen mempunyai pengaruh yang sama besar

3 = Elemen yang satu sedikit lebih penting daripada elemen yanga lainnya, Pengalaman dan penilaian sedikit menyokong satu elemen dibandingkan elemen yang lainnya
5 = Elemen yang satu lebih penting daripada yang lainnya, Pengalaman dan penilaian sangat kuat menyokong satu elemen dibandingkan elemen yang lainnya 7 = Satu elemen jelas lebih mutlak penting daripada elemen lainnya, Satu elemen yang kuat disokong dan dominan terlihat dalam praktek.

9 = Satu elemen mutlak penting daripada elemen lainnya, Bukti yang mendukung elemen yang satu terhadap elemen lain memeliki tingkat penegasan tertinggi yang mungkin menguatkan.

2,4,6,8 = Nilai-nilai antara dua nilai pertimbanganpertimbangan yang berdekatan, Nilai ini diberikan bila ada dua kompromi di antara 2 pilihan Kebalikan = Jika untuk aktivitas i mendapat satu angka dibanding dengan aktivitas $\mathrm{j}$, maka $\mathrm{j}$ mempunyai nilai kebalikannya dibanding dengan $i$

5) Menghitung nilai eigen dan menguji konsistensinya. Jika tidak konsisten maka pengambilan data diulangi.

6) Mengulangi langkah 3,4, dan 5 untuk seluruh tingkat hirarki.

7) Menghitung vektor eigen dari setiap matriks perbandingan berpasangan yang merupakan bobot setiap elemen untuk penentuan prioritas elemenelemen pada tingkat hirarki terendah sampai mencapai tujuan. Penghitungan dilakukan lewat cara menjumlahkan nilai setiap kolom dari matriks, membagi setiap nilai dari kolom dengan total kolom yang bersangkutan untuk memperoleh normalisasi matriks, dan menjumlahkan nilai-nilai dari setiap baris dan membaginya dengan jumlah elemen untuk mendapatkan rata-rata.

8) Memeriksa konsistensi hirarki.

Yang diukur dalam AHP adalah rasio konsistensi dengan melihat index konsistensi. Konsistensi yang diharapkan adalah yang mendekati sempurna agar menghasilkan keputusan yang mendekati valid. Walaupun sulit untuk mencapai yang sempurna, rasio konsistensi diharapkan kurang dari atau sama dengan $10 \%$.

\section{METODOLOGI PENELITIAN}

\section{A. Objek Penelitian}

Objek penelitian dalam Sistem Pendukung Keputusan Pemilihan Karyawan adalah STMIK Atma Luhur Pangkalpinang

B. Jenis dan Sumber Data

1. Data Kualitatif

Jenis data yang digunakan dalam penelitian adalah data kualitatif. Merupakan serangkaian observasi yang dilakukan oleh peneliti dan kemungkinan tidak dapat dinyatakan dalam angka

2. Data Kuantitatif

Jenis data kuantitatif merupakan serangkaian observasi yang dilakukan oleh peneliti dimana tiap 
observasi yang terdapat dalam sample dinyatakan dalam hasil tes dan perhitungan dengan menggunakan metode AHP.

3. Sumber data

Sumber data yang digunakan adalah :

a. Data pimer

Yaitu data yang diperoleh secara langsung dari sumber data atau obyek penelitian yaitu berupa dokumen-dokumen yang berkaitan dengan seleksi penerimaan karyawan

b. Data sekunder

Meliputi semua data yang diperoleh secara tidak langsung terhadap sumber informasi, antara lain studi pustaka, buku-buku ilmiah dan literature-literatur lain yang mendukung penelitian

\section{HASIL DAN IMPLEMENTASI}
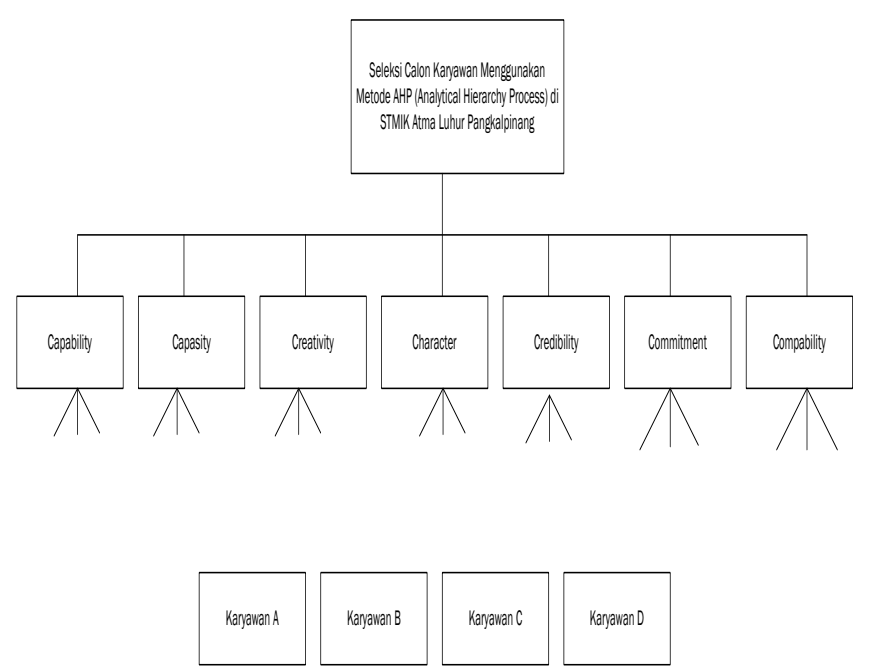

Gambar 1. Model Hirarki

$\begin{aligned} \text { Prionities with respect to: } & \text { Combined } \\ \text { Goak seleksi Calon Kanawaran } & \end{aligned}$

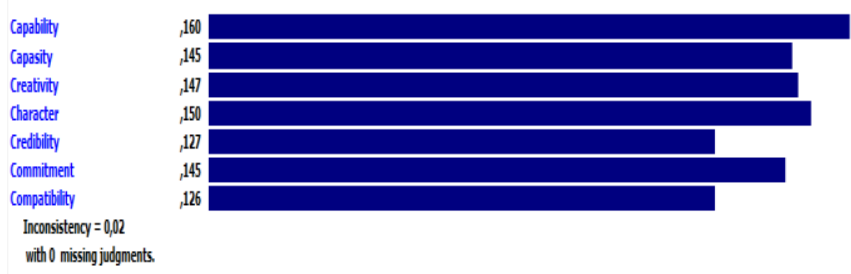

Gambar 2. Kriteria yang harus dipertimbangkan dalam seleksi calon karyawan beserta nilai bobotnya

Berdasarkan hasil pengolahan data responden ahli diperoleh bahwa prioritas utama atau tertinggi yaitu kriteria capability dengan nilai bobot 0,160 atau sebanding dengan $16,0 \%$ dari total kriteria. Peringkat prioritas kriteria berikutnya adalah character dengan nilai bobot 0,150 atau sebanding dengan $15,0 \%$ dari total kriteria. Peringkat prioritas kriteria berikutnya adalah creativity dengan nilai bobot 0,147 atau sebanding dengan $14,7 \%$ dari total kriteria. Peringkat prioritas berikutnya adalah capasity dan commitment dengan nilai bobot 0,145 atau sebanding dengan $14,5 \%$ dari total kriteria. Peringkat prioritas berikutnya adalah credibility dengan nilai bobot 0,127 atau sebanding dengan $12,7 \%$ dari total kriteria. Peringkat prioritas terakhir adalah compatibility dengan nilai bobot 0,126 atau sebanding dengan $12,6 \%$ dari total kriteria.

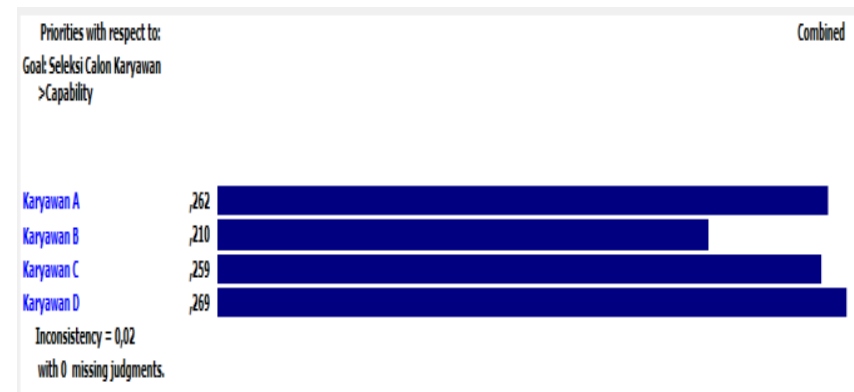

Gambar 3. Nilai bobot prioritas alternatif berdasarkan seleksi calon karyawan kriteria capability

Berdasarkan hasil pengolahan data responden ahli diperoleh bahwa prioritas utama atau tertinggi yaitu alternatif karyawan D dengan nilai bobot 0,269 atau sebanding dengan 26,9\% dari total alternatif. Peringkat prioritas alternatif berikutnya adalah karyawan A dengan nilai bobot 0,262 atau sebanding dengan $26,2 \%$ dari total alternatif. Peringkat prioritas alternatif berikutnya adalah karyawan $\mathrm{C}$ dengan nilai bobot 0,259 atau sebanding dengan $25,9 \%$ dari total alternatif. Peringkat prioritas alternatif berikutnya adalah karyawan B dengan nilai bobot 0,210 atau sebanding dengan $21,0 \%$ dari total alternatif.

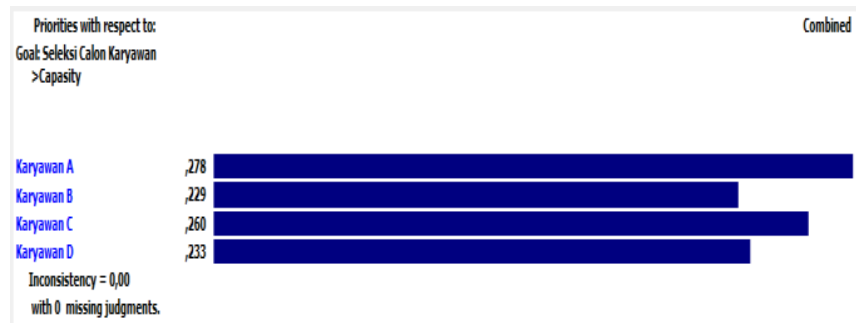

Gambar 4. Nilai bobot prioritas alternatif berdasarkan seleksi calon karyawan kriteria capacity

Berdasarkan hasil pengolahan data responden ahli diperoleh bahwa prioritas utama atau tertinggi yaitu alternatif karyawan A dengan nilai bobot 0,278 atau sebanding dengan 27,8\% dari total alternatif. Peringkat prioritas alternatif berikutnya adalah karyawan $\mathrm{C}$ dengan nilai bobot 0,260 atau sebanding dengan 26,0\% dari total alternatif. Peringkat prioritas alternatif berikutnya adalah karyawan $\mathrm{D}$ dengan nilai bobot 0,233 atau 
sebanding dengan $23,3 \%$ dari total alternatif. Peringkat prioritas alternatif berikutnya adalah karyawan B dengan nilai bobot 0,229 atau sebanding dengan 22,9\% dari total alternatif.

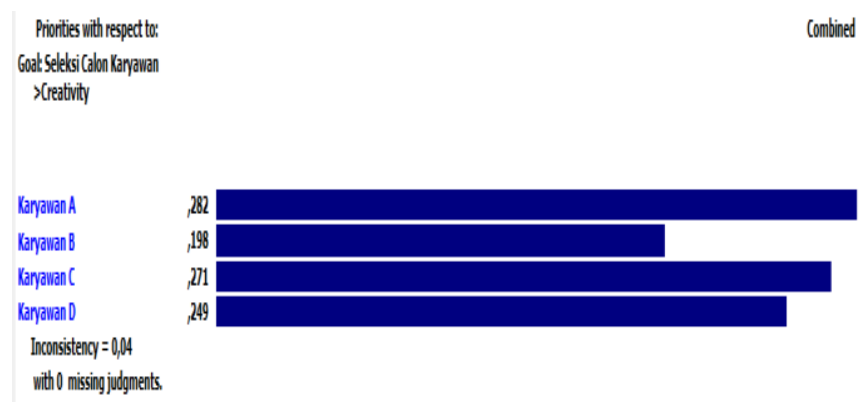

Gambar 5. Nilai bobot prioritas alternatif berdasarkan seleksi calon karyawan kriteria creativity

Berdasarkan hasil pengolahan data responden ahli diperoleh bahwa prioritas utama atau tertinggi yaitu alternatif karyawan A dengan nilai bobot 0,282 atau sebanding dengan 28,2\% dari total alternatif. Peringkat prioritas alternatif berikutnya adalah karyawan $\mathrm{C}$ dengan nilai bobot 0,271 atau sebanding dengan $27,1 \%$ dari total alternatif. Peringkat prioritas alternatif berikutnya adalah karyawan D dengan nilai bobot 0,249 atau sebanding dengan $24,9 \%$ dari total alternatif. Peringkat prioritas alternatif berikutnya adalah karyawan B dengan nilai bobot 0,198 atau sebanding dengan $19,8 \%$ dari total alternatif.

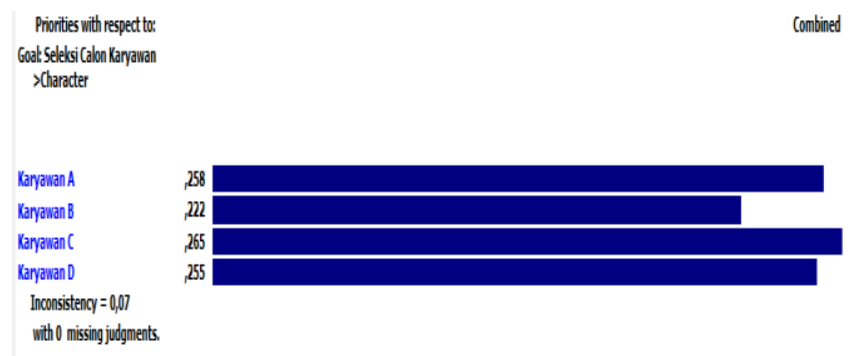

Gambar 6. Nilai bobot prioritas alternatif berdasarkan seleksi calon karyawan kriteria character

Berdasarkan hasil pengolahan data responden ahli diperoleh bahwa prioritas utama atau tertinggi yaitu alternatif karyawan C dengan nilai bobot 0,265 atau sebanding dengan $26,5 \%$ dari total alternatif. Peringkat prioritas alternatif berikutnya adalah karyawan A dengan nilai bobot 0,258 atau sebanding dengan $25,8 \%$ dari total alternatif. Peringkat prioritas alternatif berikutnya adalah karyawan $\mathrm{D}$ dengan nilai bobot 0,255 atau sebanding dengan $25,5 \%$ dari total alternatif. Peringkat prioritas alternatif berikutnya adalah karyawan B dengan nilai bobot 0,222 atau sebanding dengan $22,2 \%$ dari total alternatif.
Prioribes with respect to:

Goak Seleksicalon Karyawan

>reeditity
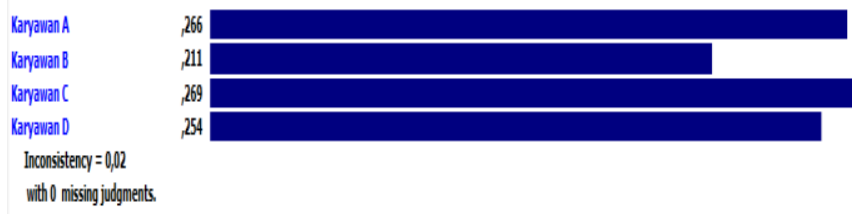

Gambar 7. Nilai bobot prioritas alternatif berdasarkan seleksi calon karyawan kriteria credibility

Berdasarkan hasil pengolahan data responden ahli diperoleh bahwa prioritas utama atau tertinggi yaitu alternatif karyawan C dengan nilai bobot 0,269 atau sebanding dengan 26,9\% dari total alternatif. Peringkat prioritas alternatif berikutnya adalah karyawan A dengan nilai bobot 0,266 atau sebanding dengan $26,6 \%$ dari total alternatif. Peringkat prioritas alternatif berikutnya adalah karyawan $\mathrm{D}$ dengan nilai bobot 0,254 atau sebanding dengan $25,4 \%$ dari total alternatif. Peringkat prioritas alternatif berikutnya adalah karyawan B dengan nilai bobot 0,211 atau sebanding dengan $21,1 \%$ dari total alternatif.

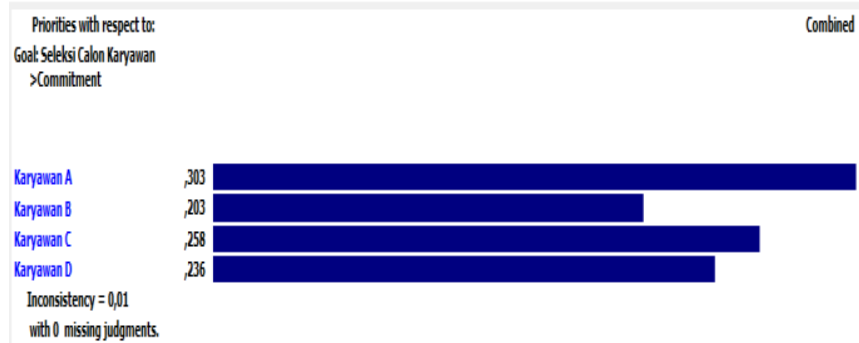

Gambar 8. Nilai bobot prioritas alternatif berdasarkan seleksi calon karyawan kriteria commitment

Berdasarkan hasil pengolahan data responden ahli diperoleh bahwa prioritas utama atau tertinggi yaitu alternatif karyawan A dengan nilai bobot 0,303 atau sebanding dengan 30,3\% dari total alternatif. Peringkat prioritas alternatif berikutnya adalah karyawan $\mathrm{C}$ dengan nilai bobot 0,258 atau sebanding dengan $25,8 \%$ dari total alternatif. Peringkat prioritas alternatif berikutnya adalah karyawan $\mathrm{D}$ dengan nilai bobot 0,236 atau sebanding dengan 23,6\% dari total alternatif. Peringkat prioritas alternatif berikutnya adalah karyawan $\mathrm{B}$ dengan nilai bobot 0,203 atau sebanding dengan 20,3\% dari total alternatif. 


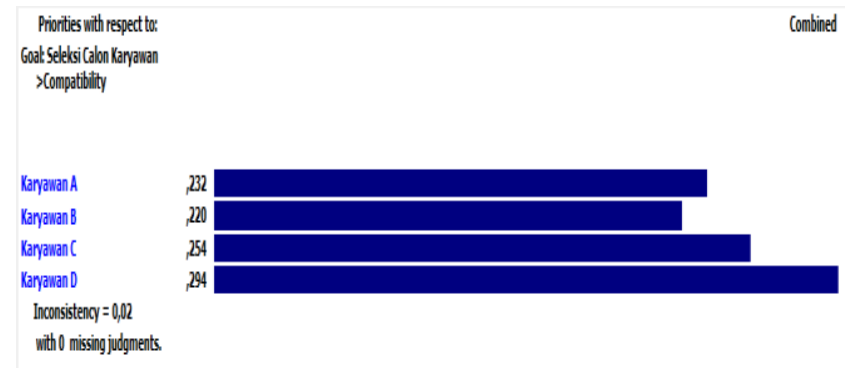

Gambar 9. Nilai bobot prioritas alternatif berdasarkan seleksi calon karyawan kriteria commitment

Berdasarkan hasil pengolahan data responden ahli diperoleh bahwa prioritas utama atau tertinggi yaitu alternatif karyawan D dengan nilai bobot 0,294 atau sebanding dengan 29,4\% dari total alternatif. Peringkat prioritas alternatif berikutnya adalah karyawan $\mathrm{C}$ dengan nilai bobot 0,254 atau sebanding dengan $25,4 \%$ dari total alternatif. Peringkat prioritas alternatif berikutnya adalah karyawan A dengan nilai bobot 0,232 atau sebanding dengan 23,2\% dari total alternatif. Peringkat prioritas alternatif berikutnya adalah karyawan B dengan nilai bobot 0,220 atau sebanding dengan 22,0\% dari total alternatif.

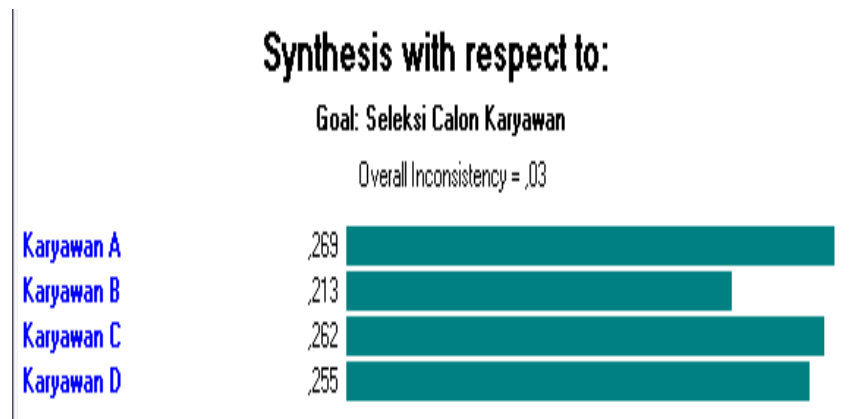

Gambar 10. Nilai Bobot Global Prioritas Alternatif

Berdasarkan Seleksi Calon Karyawan

Berdasarkan hasil pengolahan data responden ahli diperoleh bahwa prioritas utama atau tertinggi alternative adalah "Karyawan A" dengan nilai bobot 0,269 atau sebanding dengan 26,9\% dari total alternative yang ditetapkan. Peringkat prioritas alternative berikutnya adalah "Karyawan C" dengan nilai bobot 0,262 atau sebanding dengan $26,2 \%$ dari total alternative yang ditetapkan. Peringkat prioritas alternative berikutnya adalah "Karyawan D" dengan nilai bobot 0,255 atau sebanding dengan 25,5\% dari total alternative yang ditetapkan. Peringkat prioritas alternative yang terkahir adalah "Karyawan B" dengan nilai bobot 0,213 atau sebanding dengan 21,3\% dari total alternative yang ditetapkan.

\section{PENUTUP}

Dari hasil penelitian dapat disimpulkan bahwa Karyawan A menjadi prioritas dalam seleksi calon karyawan yaitu dengan bobot 0,269 , urutan selanjutnya Karyawan $\mathrm{C}$ dengan bobot 0,262, diikuti Karyawan D dengan bobot 0,255 dan terakhir Karyawan B dengan bobot 0,213.

\section{DAFTAR PUSTAKA}

[1] Thomas L.Saaty, Theory and Applications of the Analytic Network Process : Decision Making with Benefits, Opportunities, Cost, and Risks, RWS Publications, 2005, ISBN 1-888603-06-2

[2] Banureaj, J.M.F, Prinsip Kerja AHP. Diakses dari https://sites.google.com/site/banureaj/ta-jonas/ahp/prinsip-kerja-ahp pada tanggal 23 Februari 2019, jam 4.16 WIB.

[3] Thomas L.Saaty, NEW! Creative Thinking, Problem Solving \& Decision Making, RWS Publications, 2005 (new ed). ISBN-1-888603-03-8

[4] Thomas L.Saaty, The Analytic Network Process: Decision Making with Dependence and Feedback, 2001.ISBN 0-9620317-9-8

[5] Thomas L.Saaty and Mujigan Ozdemir, The Encyclion; a Dictionary of Applications of Decision Making with Dependence and Feedback based on the Analytic Network Process,RWS Publications, 2005.ISBN 1-888603-05-4

[6] John W.Creswell, Research Design: Qualitative, Quantitative \& Mixed Methods Approaches, Sage Publications,Inc, 2014

[7] Bourgeois, R. 2005. Analytical Hierarchy Process: an Overview UNCAPSA - UNESCAP. Bogor.

[8] Kusrini, Konsep dan Aplikasi Sistem Pendukung Keputusan, Andi Offset, Yogyakarta, 2009

[9] Sugiyono, Metode Penelitian Kuantitatif Kualitatif dan R\&D, Alfabeta, Bandung, 2008

[10] Harjanto, Arif, Sistem Pendukung Keputusan Seleksi Calon Karyawan Berdasarkan Hasil Tes Psikologi Kepribadian Menggunakan Metode AHP, Jurnal Informatika,Volume 14 Nomor 1,Juni 2014 